УДК: 001.8:[005.334.658.15:657.635]

JEL Classification: M 42

С. В. СЕЛЩЕВ,

кандидат економічних наук, доиент Національного иентру обліку та аудиту, Національна академія статистики, обліку та аудиту,

\title{
Вартісна модель оцінки ризику припинення діяльності підприємств у аудиті
}

У статті досліджено підхід до оцінки ризику припинення діяльності підприсмства иляхом побудови вартісноїмоделі. Така модель надає аудитору інформачію про розуміння та адекватність сприйняття управлінським персоналом факторів впливу на зміну вартості активів $i$ зобов 'язань, а також методів, за допомогою якихможна найбільи ефективно та достовірно ї̈ визначити. На основі такої інформації аудитор може оцінити адекватність застосування припущення про безперервність діяльності підприємства при підготовці управлінським персоналом фінансових звітів.

Ключові слова: припущення про безперервність, вартість, аудит, аудиторський ризик, методи.

Вступ. Важливою обставиною сталого функціонування і становлення економічної системи країни постає реалізація успішних інвестиційних стратегій, що гарантує активні відтворювальні процеси, збільшення валового внутрішнього продукту, формування та розвиток нових секторів економічної діяльності. Головною метою реалізації інвестиційних процесів за умов несприятливого конкурентного середовища, перш за все, вважається отримання найбільшого прибутку за найменших витрат коштів. Разом із тим, фінансова невизначеність спричиняє реальний прояв факторів утворення ризиків виникнення витрат, недоотримання прибутку через їх прояв, які в перспективі зможуть послужити причиною припинення роботи компанії i, в свою чергу, мають бути передбачені при оцінці аудитором адекватності використання судження про безперервність діяльності при підготовці фінансових звітів керівництвом компанії.

Аналіз досліджень і публікацій. Розробленню методичних підходів до оцінки вартості компаній присвячені праці Г. Кіндрацької, Р. Костирко, Н. Тертичної [5; 6, 10$]$. Ряд робіт присвячено питанням оцінки ризиків у аудиті [1-6; 9]. Але слід підкреслити, що питання методології оцінки аудиторського ризику через аналіз застосовуваних методів визначення вартості підприємства на сьогодні ще $є$ практично не вивченим.

Мета статті - дослідження та розроблення методології застосування вартісних моделей оцінки ризику припинення діяльності підприємства в аудиті.

Виклад основного матеріалу. Виходячи з аналізу поточної практики аудиту при дослідженні прийнятих управлінським персоналом економічних рішень, пов'язаних із оцінкою вартості підприємства, аудитору необхідно враховувати характер ризиків, пов'язаних $з$ такою оцінкою, та ймовірність їх виникнення. Зазвичай складність такої оцінки обумовлюється мультифакторною динамікою формування суб'єкта оцінки і нестабільними критеріями його функціонування. Зокрема, в аспекті оцінки ризику припинення діяльності це стосується ступеня відповідності та адекватності оцінки вартості компанії, що відображає можливий ступінь небезпеки.

Визначення аудиторського ризику, пов'язаного з неправильною оцінкою вартості компанії, вважається однією з головних стадій процесу оцінки ризику припинення діяльності, оскільки його ймовірність обумовлює стратегію проведення аудиту. Вивчення суті і значення ризиків у процесах оцінки вартості компанії набуває особливої важливості і вважається головним компонентом концепції формування теоретикометодологічного забезпечення аудиту. Виявлення суті і типів ризиків, пов'язаних iз неправильним оцінюванням вартості компанії, гарантує можливість розроблення

(C) С. В. Селіщев, 2017

НАУКОВИЙ ВІСНИК НАЦІОНАЛЬНОЇ АКАДЕМІІ

СТАТИСТИКИ, ОБЛІКУ ТА АУДИТУ, 2017, № 4 
нових методологічних підходів для оперативного визначення і мінімізації негативних наслідків ії неправильного оцінювання.

В ході оцінювання вартості компанії виявляються 2 групи ризиків: ризики діяльності компанії і ризики неадекватності процесу оцінювання.

Перша група ризиків - це ризики діяльності компанії, які можуть бути зовнішніми та внутрішніми.

Зовнішні ризики визначаються характером сектору економіки, в якому діє підприємство. Можна виділити такі їх фактори:

- нестабільність фінансового стану та низькі темпи розвитку сектору економічної діяльності компанії;

- високий рівень конкуренції всередині сектору економічної діяльності компанії;

- обмеження прав компанії муніципальними органами і посадовими особами.

Друга група ризиків - це ризик неадекватності оцінки, який, у свою чергу, може бути професійним (низька кваліфікація) або інформаційним (неповнота інформаціі). Тобто цей ризик визначається ступенем професіоналізму суб'єкта оцінки і його допуском до інформації. Можна виділити низку факторів, що обумовлюють ризики другої групи:

- нераціональний поділ роботи між суб'єктами аналізу;

- невідповідність індивідуальних можливостей суб'єкта оцінки структурі та змісту виконуваних робіт;

- неоптимальне координування інформаційних потоків у межах підприємства;

- розповсюдження даних, що складають комерційну таємницю.

Отже, модель оцінки ризику неправильного визначення вартості компанії виглядатиме таким чином:

Ризик визначення вартості $=$ зовнішній ризик діяльності $*$ внутрішній ризик діяльності * професійний ризик неадекватності оцінки * інформаційний ризик неадекватності оцінки.

Незважаючи на значущість усіх показників, при оцінці ризиків, пов'язаних із визначенням вартості компанії, аудитору слід приділити окрему увагу професійним (кваліфікаційним) якостям управлінського персоналу.

Проявами зовнішніх ризиків оцінки вартості компанії можуть бути:

- можливість посилення конкурентної боротьби, що проявляється через зниження обсягу продажів унаслідок входження на ринок більш сильних конкурентів, раніше не відомих товарів-субститутів, інтенсивну маркетингову політику старих і нових конкурентів;

- ризик, пов'язаний зі зміною обмінного курсу національної валюти;

- ризик зміни потреб або платоспроможності покупців, що найбільш властиво для порівняно дорогих інвестиційних товарів і побутових товарів довготривалого використання.

Зокрема, на ризик припинення діяльності підприємства може вплинути наявність активів, придбаних на умовах кредитування в іноземній валюті. На тлі стрімких коливань валютних курсів вартість підприємства може змінитись у декілька разів за короткий проміжок часу.

При аналізі внутрішніх ризиків оцінки вартості компанії доцільно звернути увагу на такі явища:

- відсутність чіткої концепції розподілу і делегування повноважень в організації управління підприємством;

- незадовільний рівень диверсифікації продукції і господарської діяльності, що заважає своєчасному переходу на нові різновиди продукції і послуг;

- загроза збільшення питомої ваги дебіторської заборгованості в капіталі компанії;

- дефіцит грошових коштів або інших високоліквідних активів для забезпечення виконання зобов'язань перед контрагентами.

Другим елементом аудиторського ризику визначення вартості компанії є можливість неадекватності отриманої оцінки, що визначає невідповідність побудованої факторної моделі причин зміни вартості. Такого роду ризик з'являється через застосування моделі, недоречної для цілей оцінювання, може бути пов'язаний із незадовільною кваліфікацією суб'єкта оцінювання або недостатністю відповідної інформації, що може 
призводити до формулювання невірних результатів оцінки. 3 метою мінімізації ризиків оцінки слід встановити величину суттєвості похибки оцінювання, яка може бути ознакою ризику припинення діяльності, виконати процедури вивчення сприйнятливості суб'єкта оцінки до ризиків.

Найбільш поширеними методами визначення ризиків є такі: метод сценаріїв, аналітичний метод і метод аналогії [7; 8; 10].

Метод сценаріїв застосовується для встановлення для кожного виокремленого фактора підвищення ризику песимістичного, оптимістичного і найбільш імовірного сценарію. В подальшому для визначеного фактора, наприклад для інфляційного ризику, змінюється безризикова ставка дисконту, яка повинна використовуватися для встановлення поточної вартості скоригованих фінансових потоків.

Водночас при оцінці ризиків можливого викривлення результатів оцінки вартості підприємства за допомогою цього методу аудитору слід звернути увагу на такі його недоліки:

- ставка дисконту ніяк не передбачає очікувань щодо ризиків різних користувачів фінансової звітності;

- модель передбачає тільки періодичні, повторювані ризики діяльності;

- у визначеній ставці дисконту облік ризиків здійснюється виходячи з розрахунку на учасників, які не реалізовуватимуть активи в осяжному майбутньому.

Метод аналогій при оцінці ризиків діяльності компанії грунтується на дослідженні впливу умов зміни рівня ризику оцінки результатів реалізованих інвестиційних планів компаній того ж сектору економіки або аналогічних компаній. Цей метод вважається максимально теоретичним та конкретним 3-серед усіх інших методів оцінки ризиків викривлення вартості, оскільки він цілком грунтується на інформації щодо ринку і включає мінімум непідтвердженої інформації.

Разом із тим, низький темп зростання вітчизняного фондового ринку, значна асиметричність даних щодо розвитку економіки створюють перешкоди для оцінювання і ставлять під підозру надійність висновків, отриманих із застосуванням методу аналогій. Для отримання доказів застосування методу аналогій аудитору слід впевнитись в надійності, релевантності та достовірності джерел інформації про суб'єкти господарювання, на базі яких здійснювалось аналогічне моделювання.

Аналіз сприйнятливості до факторів підвищення ризику невизначеності (далі сприйнятливості) вважається одним з найбільш легких і популярних способів ідентифікації причин невизначеності, властивих для оцінки виробничих проектів. Він зазвичай передує кількісній оцінці ризиків і надає можливість виявити, які з оцінюваних умов можливо включити до максимально небезпечних.

Доцільність застосування аналізу сприйнятливості при встановленні ризиків оцінки вартості компанії забезпечується об'єктивністю і простотою розрахунків. Встановлені результати надають можливість ідентифікувати параметри економічної діяльності, гранична зміна яких впливає на остаточне значення основного параметра ймовірності припинення діяльності. Аудитору доцільно звернути увагу на процес, через який, визначивши критичні значення причин ризику, суб'єкт оцінки розробляє концепцію заходів щодо запобігання їх появу і мінімізації їх негативного впливу.

Проведення процедур оцінки ризиків формування вартості компанії визначає необхідність побудови належної інформаційної бази. Головними джерелами даних для визначення ризику оцінки вартості компанії вважаються: внутрішні (бухгалтерська документація, контракти, товаророзпорядчі документи, технологічні карти) і зовнішні свідоцтва (нормативно-правові акти, матеріали періодичних видань, інформація про діяльність компаній-аналогів, документи спеціалізованих компаній, що займаються збиранням фінансової та нефінансової інформації); результати, отримані через проведення досліджень і опитувань; відомості про зв'язки компанії, характер формування основних показників сектору економіки, в якому діє компанія.

Перелік визначених умов економічної діяльності і небезпек компанії залежить від особливостей ії̈ зовнішнього та внутрішнього бізнес-середовища, стадій виробничого циклу і співвідношення між попитом та пропозицію на ії товари (послуги), раптових змін законодавства, структури їі активів, адекватності оцінки їі фінансового стану, стійкості іiї економічного становища. 
Ідентифіковані небезпеки і фактори підвищення ризику визначають необхідність застосування певних методів його оцінки (сценаріїв, аналогії і т. д.).

Застосування запропонованої методології оцінки ризиків дає можливість встановити прийнятність рівня ризикку припинення діяльності, пов'язаного з оцінкою вартості компанії. Встановлений показник ризику забезпечує базу для висновку про доречність та професійність застосовуваних методів.

Висновки. Аналіз методологічних підходів до оцінки ризику припинення діяльності підприємства в ході аудиту дозволяє стверджувати, що одним із методологічних підходів до ідентифікації та оцінки таких ризиків може бути використання вартісних моделей.

Аналіз наведених методів дозволяє зрозуміти існуючу систему оцінки вартості підприємства, інтегровану в систему управління, та наслідки їі функціонування - тобто безпосередньо порівняння даних про ціну активів за даними бухгалтерського обліку та ринковою ціною цих активів. Завищення або заниження вартості підприємства може бути ознакою майбутньої реалізації або ліквідації підприємства, що, у свою чергу, може бути ознакою високої ймовірності припинення його діяльності.

Неправильний вибір або застосування методів оцінки вартості підприємства може свідчити про ризик отримання ненадійної та нерелевантної інформації користувачами фінансових звітів.

Вивчення методів оцінки вартості підприємства є основою розроблення методологічної концепції процедурного забезпечення аудиту системи прийняття адміністративних рішень щодо питань розроблення та коригування процесу оцінки вартості майна.

\section{Список використаних джерел}

1. Данилевский Ю. А., Шапигузов С. М., Ремизов Н. А. и др. Аудит: учеб. пособ. М.: ИД ФБК-ПРЕСС, 2000. 544 с.

2. Бутинець Ф. Ф. Економічний аналіз: навч. посіб. Житомир: ПП "Рута", 2001. 416 с.

3. Гончарук Я. А., Рудницький В. С. Аудит: навч. посіб. Львів: Світ, 2002. 296 с.

4. Давидов Г. М. Аудит: підруч. К.: Ліга, 2004. 336 с.

5. Кіндрацька Г. І., Білик М. С., Загородній А. Г. Економічний аналіз: підруч. К.: Знання, 2008. 487 с.

6. Костирко Р. О. Комплексна оцінка вартості підприємства: навч. посіб. Х.: Фактор, 2007. $784 \mathrm{c}$.

7. Кулаковська Л. П., Піча Ю. В. Організація і методика аудиту: підруч. К.: Каравела, 2009. $544 \mathrm{c}$.

8. Петрик О. А. Аудит: методологія та організація: моногр. К.: КНЕУ, 2003. 260 с.

9. Проскуріна Н. М. Процедурне забезпечення аудиту. Теорія та практика: моногр. К.: ДП "Інформ.-аналіт. агентство", 2011. 739 с.

10. Тертична Н. В. Комплексна оцінка вартості підприємства: автореф. дис. ... канд. екон. наук: спец. 08.06.01 "Економіка, організація і управління підприємствами". Луганськ, 2006. 19 с.

С. В. СЕЛИЩЕВ, кандидат экономических наук, доцент Национального иеетра учета и аудита, Национальная академия статистики, учета и аудита

\section{Стоимостная модель оценки риска деятельности предприятий в аудите}

В статье исследован подход к оченке риска прекращееия деятельности предприятия путем построения стоимостной модели. Такая модель предоставляет аудитору информацию о понимании и адекватности восприятия руководством факторов влияния на изменение стоимости активов, обязательств, а также методов, с помощьью которых можно наиболее эффективно и достоверно ее определить. На 


\section{ВАРТІСНА МОДЕЛЬ ОЦІНКИ РИЗИКУ \\ ПРИПИНЕННЯ ДІЯЛЬНОСТІ ПЦДПРИЕМСТВ У АУДИТІ}

основе такой информации аудитор может оценить адекватность применения предположения о непрерывности деятельности предприятия при подготовке руководством финансовых отчетов.

Ключевые слова: предположение о непрерывности, стоимость, аудит, аудиторский риск, методь.

S. V. SELISHCHEV, PhD (Economics) Assistant Professor of National Centerfor Accounting and Audit, National Academy of Statistics, Accounting and Auditing

\section{Cost Model for Risk Assessment of Company Operation in Audit}

This article explores the approach to assessing the risk of company activities termination by building a cost model. This model gives auditors information on managers' understanding of factors influencing change in the value of assets and liabilities, and the methods to identify it in more effective and reliable ways. Based on this information, the auditor can assess the adequacy of use of the assumption on continuity of company operation by management personnel when preparing financial statements.

Financial uncertainty entails real manifestations offactors creating risks of the occurrence of costs, revenue losses due their manifestations, which in the long run can be a reason for termination of company operation, and, therefore, need to beforeseen in the auditor's assessment of the adequacy of use of the continuity assumption when preparing financial statements by company management.

The purpose of the study is to explore and develop a methodology for use of cost models to assess the risk of termination of company operation in audit.

The issue of methodologyfor assessing the audit risk through analyzing methods for company valuation has not been dealt with. The review of methodologies for assessing the risks of termination of company operation in course of audit gives grounds for the conclusion that use of cost models can be an effective methodology for identification and assessment of such risks.

The analysis of the above methods gives understanding of the existing system for company valuation, integrated into the management system, and the consequences of its use, $i$. e. comparison of the asset price data with the accounting data and the market value of the asset data. Overvalued or undervalued company assets may be a sign of future sale or liquidation of a company, which may signal on high probability of termination of company operation. A wrong choice or application ofvaluation methods can be indicative of the risk of non-reliable and non-relevant information received by users offinancial statements. The study of methods for assessing the company value lays the basisfor developing a methodological guideline of the procedural support for audit of administrative decision making on valuation and revaluation of assets.

Key words: assumption on continuity, cost, audit, audit risk, methods.

\section{Посилання на статтю:}

Селіщев С. В. Вартісна модель оцінки ризику припинення діяльності підприємств у аудиті // Науковий вісник Національної академії статистики, обліку та аудиту: зб. наук. пр.. 2017. №4. С. 59-63. 